\title{
DNA Breakage by Salvianolic acid B in the Presence of Cu (II)
}

\author{
Pyeongjae Lee ${ }^{1}$, Cheol Moon ${ }^{2}$, Yoon Seon $\mathrm{Choi}^{3}$, Hyun Kyu Son ${ }^{4}$ \\ ${ }^{1}$ School of Industrial Bio-pharmaceutical Science, Semyung University, Jecheon, Korea \\ ${ }^{2}$ Department of Clinical Laboratory Science, Semyung University, Jecheon, Korea \\ ${ }^{3}$ Department of Cosmetic Science, Semyung University, Jecheon, Korea \\ ${ }^{4}$ Department of Natural Medicine Resources, Semyung University, Jecheon, Korea
}

\section{구리이온(II)이 존재할 때 Salvianolic acid B에 의한 DNA 절단}

\author{
이평재 ${ }^{1}$, 문 철 $^{2}$, 최윤선 $^{3}$, 손현규 $^{4}$ \\ ${ }^{1}$ 세명대학교 바이오제약산업학부, ${ }^{2}$ 세명대학교 임상병리학과, ${ }^{3}$ 세명대학교 화장품과학과, ${ }^{4}$ 세명대학교 자연약재과학과
}

\begin{abstract}
Salvianolic acid B, which is a compound in the Salvia miltiorrhiza, has diverse biological activities, In particular, the antioxidative effects were reported to be involved in the protection of hepatocytes, neurons, and various cell types. On the other hand, some phenolic compounds, such as ferulic acid, which is regarded as an antioxidant, plays a pro-oxidative role in the specific transitional metal environment, which could explain the anticancer effect. This study examined the pro-oxidative effects of salvianolic acid B in the presence of $\mathrm{Cu}^{2+}$. Treatment with both salvianolic acid B and $\mathrm{Cu}^{2+}$ induced the transition of supercoiled DNA to the open circular or linear form but not in the sole salvianolic acid B or $\mathrm{Cu}^{2+}$ treatments. Salvianolic acid $\mathrm{B}$ reduced the $\mathrm{Cu}^{2+}$ to $\mathrm{Cu}^{+}$using neocuproine, $\mathrm{aCu}^{+}$specific chelator. In addition, catalase, an enzyme that breaks down the $\mathrm{H}_{2} \mathrm{O}_{2}$ to water and molecular oxygen, inhibited the DNA breakage. $\mathrm{H}_{2} \mathrm{O}_{2}$, a reactive oxygen species, has detrimental effects on biological molecules, particularly DNA. Overall, the reduction of $\mathrm{Cu}^{2+}$ by salvianolic acid $\mathrm{B}$ could lead to the production of $\mathrm{H}_{2} \mathrm{O}_{2}$ followed by DNA breakage. These results suggest that the pro-oxidative effects could be the one of the anti-cancer mechanisms of salvianolic acid B, which remains to be explained.
\end{abstract}

Key words: Antioxidant, Copper ion, Hydroxyl radical, Pro-oxidant, Salvianolic acid B

This is an Open Access article distributed under the terms of the Creative Commons Attribution Non-Commercial License (http://creativecommons.org/licenses/by-nc/4.0) which permits unrestricted non-commercial use, distribution, and reproduction in any medium, provided the original work is properly cited.

Copyright @ 2018 The Korean Society for Clinical Laboratory Science. All rights reserved.
Corresponding author: Pyeongjae Lee School of Industrial Bio-pharmaceutical Science, Semyung University, 65 Semyung-ro, Jecheon 27136, Korea

Tel: 82-43-649-1411

Fax: 82-43-649-1729

E-mail: pjlee1@semyung.ac.kr

Received: February 9, 2018

Revised $1^{\text {st. }}$ : March 21, 2018

Revised 2 ${ }^{\text {nd }}$ : May 16, 2018

Revised 3 $3^{\text {rd }}$ : May 21, 2018

Accepted: May 22, 2018

\section{서 론}

산소는 세포에서 ATP를 생성하기위한 호흡기능에 필수적 요 소이다. 미토콘드리아에서 전자전달계를 거친 전자는 최종적 으로 산소가 수용하는데 전자전달계를 이탈한 전자는 산소와 반응하여 superoxide radical $\left(\cdot \mathrm{O}^{2-}\right)$, hydrogen peroxide $\left(\mathrm{H}_{2} \mathrm{O}_{2}\right)$, hydroxyl radical $(\cdot \mathrm{OH})$ 등 반응성이 강한 활성산소종 (Reactive Oxygen Species: ROS)을 생성하게 된다. 때로는 이 와 다른 화학적 반응을 통해 ROS를 생성하기도 하는데 이렇게
생성된 활성산소종은 세포를 구성하는 핵산, 단백질, 지질의 구 조를 변화시키고 이는 세포의 기능에 심각한 손상을 줄 수 있다. 이를 oxidative stress (OS) 라 부르며 퇴행성질환 및 노화에 있 어 주요한 원인으로 여겨지고 있다. 생명체는 ROS를 방어하는 시스템을 구축하여 대응한다. Superoxide dismutase (SOD)와 catalase 등의 효소시스템은 생성된 ROS를 안전한 $\mathrm{H} 2 \mathrm{O}$ 로 변 환시키며 체내 ROS를 제거 하는 항산화 물질을 가지고 있기도 하다[1-2].

$\mathrm{ROS}$ 가 세포에 부정적 영향을 주기도 하지만 생명체는 ROS 
를 유용하게 이용하기도 한다. $\mathrm{DNA}$, 단백질, 지질의 변형을 가 져오는 ROS는 외부로부터 침입한 병원체 등을 제거하기 위한 자기생체방어시스템으로서의 역할을 수행하기도 하고 세포간 의 신호전달물질로서의 역할을 하기도 한다[3].

$\mathrm{OS}$ 로 인한 질병의 발생과 노화를 예방 혹은 치료를 위해 그동 안 생명체의 방어시스템을 강화시키거나 혹은 ROS를 소거하는 항산화효능을 가지는 소재에 대해 연구되어 보고되어 왔다. 하 지만 항산화효능이 뛰어나다고 알려진 물질도 $\mathrm{Cu}^{2+}$ 과 같은 산 화형의 전이금속이 있는 환경에서 오히려 pro-oxidant로서 ROS를 만들어 낼 수 있음(Figure 1)이 알려져 있고 [4-5] 이것이 암세포를 사멸시키는 기전 중에 하나라고 보고 있기도 하다 [6-8]. 이는 물질이 가지는 다양한 면을 보여주고 있는 것으로 때론 항산화물질로서 때론 pro-oxidant로 유용하게 이용할 수 도 있음을 보여주고 있다고 생각한다.

단삼(Salvia miltiorrhiza Bunge)은 중앙 - 서아메리카, 중앙 동 아시아에 분포하는 꿀풀과에 속하는 다년생 초본식물로서 뿌리를 약용으로 사용한다. 단삼에 포함되어있는 주요 성분은 diterpene 화합물에 포함되는 tanshinone I, IIA, IIB 등 과 phenolic 화합물에 포함되는 danshensu, protocatechuic aldehyde, salvianolic acid B 등이 알려져 있다[9]. 이전 연구 에 따르면 단삼에 포함되어있는 주요 성분 중 Salvianolic acid $\mathrm{B}$ 는 간보호, 혈관보호, 신경세포보호 등의 생리활성 기능과 함 께 superoxide radical과 hydroxyl radical를 소거하는 항산화 효과를 가지고 있다[10-14]. 위에서 설명했듯이 phenolic compounds 들이 pro-oxidant로 작용하여 $\mathrm{ROS}$ 중 특히 hydroxyl radical을 생성한다고 보고가 있으며 이를 phenolic compound의 항암 작용의 하나의 기전으로 설명하기도 한다. 본 실험에서는 단삼의 주요한 생리활성 물질이며 항산화 효과 가 있다고 알려진 salvianolic acid B를 대상으로 pro-oxidant 로서의 기능하는지 확인하는 실험을 진행하였다.

\section{재료 및 방법}

\section{1. 실험재료}

본 실험에 사용한 3-(2-Pyridyl)-5,6-diphenyl-1,2,4triazine-4’,4”-disulfonic acid sodium salt (Ferrozine),

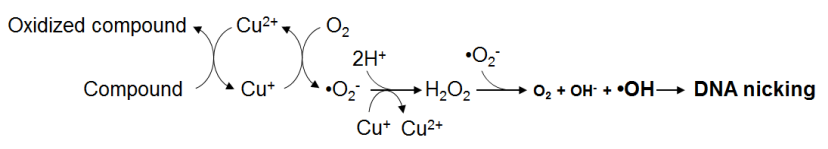

Figure 1. Mechanism of hydroxyl radical formation mediated by $\mathrm{Cu}^{2+}$. neocuproine, salvianolic acid B, Calf DNA는 Sigma Aldrich (St. Louis, MO, USA)에서 구입한 제품을 사용하였고, pBR322 (Plasmid)는 New England Biolabs (NEB)에서, $\mathrm{FeSO}_{4}$ 와 $\mathrm{CuSO}_{4}$ 는 Samchun Chemical에서 구입한 제품을 사용하였다.

\section{DNA nicking assay}

$\mathrm{pBR} 322$ 가 hydroxyl radical에 의해 절단이 일어나는 현상 에 salvianolic acid B가 어떠한 영향을 주는지 확인하기 위해 실행하였다. pBR322 (250 $\mu \mathrm{g} / \mathrm{mL}), \mathrm{FeSO}_{4}$ 혹은 $\mathrm{CuSO}_{4}$, salvianolic acid B를 혼합 한 후 phosphate buffer ( $\mathrm{pH}$ 7.4)를 이용하여 총부피를 $20 \mu \mathrm{L}$ 로 맞추었다. 실험에 따라 catalase 혹 은 $\mathrm{EDTA}$ 를 넣어 $20 \mu \mathrm{L}$ 로 맞추었다. Heating block을 이용하여 $37^{\circ} \mathrm{C}$ 에서 60 분간 반응 시킨 후 TAE buffer (1X)로 만든 $1 \%$ agarose gel을 만들어 전기영동 시킨 후 gel image analysis system을 사용하여 밴드의 위치를 확인하였다.

\section{Calf DNA break assay}

Calf DNA가 hydroxyl radical에 의하여 절단이 일어나는 현 상에 대하여 salvianolic acid B가 어떠한 영향을 주는지 확인하 기 위해 실행하였다. Calf DNA $(0.4 \mathrm{mg} / \mathrm{mL}$ in phosphate buffer), $\mathrm{FeSO}_{4}(2 \mathrm{mM})$, salvianolic acid B $(200 \mu \mathrm{M}, 10 \mu \mathrm{M}$, $100 \mu \mathrm{M}, 200 \mu \mathrm{M})$ 을 혼합 한 후 $\mathrm{H}_{2} \mathrm{O}$ 를 이용하여 총부피를 $40 \mu \mathrm{L}$ 로 맞추었다. Heating block을 이용하여 $37^{\circ} \mathrm{C}$ 에서 60 분 간 반응시킨 후 TAE buffer (1X)로 만든 1\% agarose gel을 만들 어 전기영동 시킨 후 gel image analysis system을 사용하여 결 과를 확인하였다.

\section{Neocuproine assay}

Salvianolic acid B에 의해 $\mathrm{Cu}^{2+}$ 가 $\mathrm{Cu}^{+}$로 변환되는지를 확인 하기 위해 $\mathrm{Cu}^{+}$과 특이적으로 결합하는 neocuproine를 이용하 였다. $\mathrm{CuSO}_{4}(100 \mu \mathrm{M})$, neocuproine $(400 \mu \mathrm{M})$, salvianolic $\operatorname{acidB}(1,5,10,100,200 \mu \mathrm{M})$ 를 혼합한 후 phosphate buffer (pH 7.4)를 이용하여 $400 \mu \mathrm{L}$ 로 맞추었다. 실온에서 10분간 반 응 시킨 후 $450 \mathrm{~nm}$ 에서 흡광도를 측정하였다.

\section{Iron 킬레이팅 assay}

Salvianolic acid B가 $\mathrm{Fe}^{2+}$ 에 대하여 chelating 효과가 있는 지 확인하기 위해 실행하였다. $\mathrm{FeSO}_{4}(200 \mu \mathrm{M})$, ferrozine $(200 \mu \mathrm{M})$, salvianolic acid B $(10 \mu \mathrm{M}, 100 \mu \mathrm{M}, 200 \mu \mathrm{M})$ 를 혼 합한 후 $\mathrm{H}_{2} \mathrm{O}$ 를 이용하여 총부피를 $400 \mu \mathrm{L}$ 로 맞추었다. 실온에 서 10 분간 반응 시킨 후 $562 \mathrm{~nm}$ 에서 흡광도를 측정하였다. 


\section{6. 통계 분석}

실험은 독립적으로 3회 반복하였다. 분석한 실험 결과 값의 통계처리는 평균값土표준편차로 나타내었으며, 실험 결과 값 의 통계적 유의성은 대조군과 각각의 시료처리 군의 실험 결과 값으로부터 Student's t-test를 통하여 검증하였다. P-value< 0.05 인 것을 통계적으로 유의한 것으로 하였다.

\section{결 과}

\section{1. $\mathrm{Fe}^{2+}$ 이온 조건에서 salvianolic acid $\mathrm{B}$ 의 DNA 절단 억제} 효과

플라스미드는 circular 형태로 supercoiled 되어 있다. 플라

A
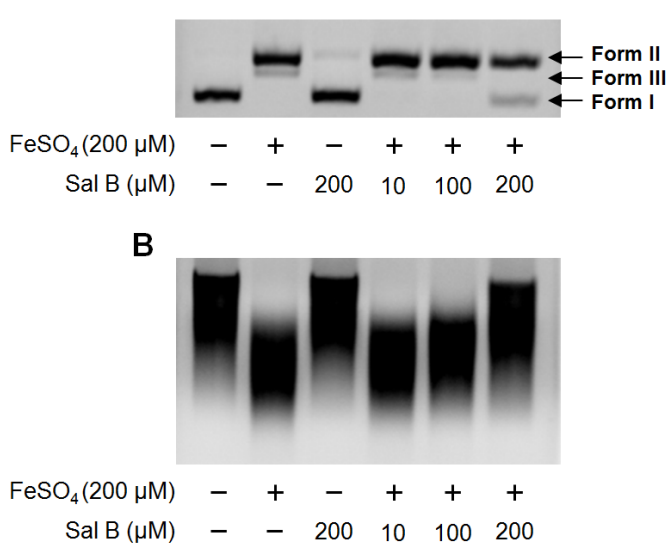

Figure 2. Inhibitory effect of salvianolic acid $B$ on nicking and breakage of plasmid (A) or calf DNA (B). Electrophoresis was performed on $1 \%$ agarose gel. Form I, supercoiled form: Form II, open circular form: Form III, linear form.

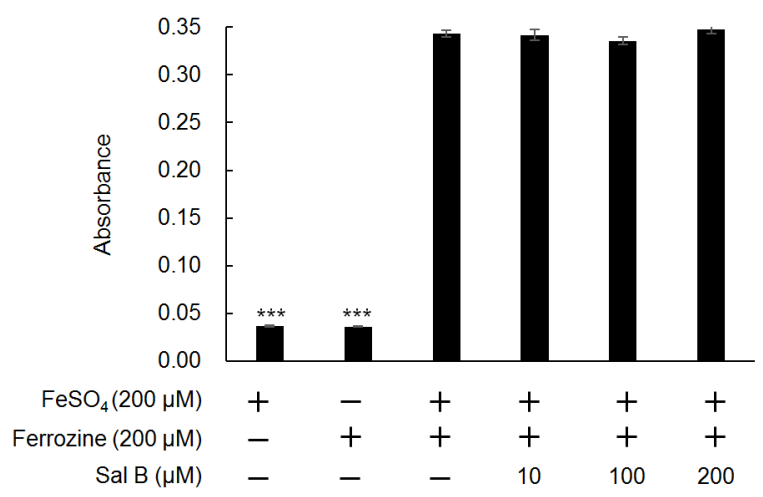

Figure 3. Complex of ferrozine and $\mathrm{Fe}^{2+}$ has the absorbance on $562 \mathrm{~nm}$. Salvianolic acid B had no effect on binding of ferrozine on $\mathrm{Fe}^{2+}$. Values represent mean $\pm \mathrm{SD}$ of three independent measurements. ${ }^{* \star *} P<0.001$; significantly different from the mixture of ferrozine and $\mathrm{Fe}^{2+}$ by Student's t-test.
스미드 DNA에 절단이 일어나면 supercoiled (form I)에서 open circular form (form II)이 되었다가 더 절단이 일어나게 되면 linear form (form III)이 되어 agarose gel에서 그 위치가 변한다. 따라서 DNA분해를 일으키는 물질을 처리했을 때 겔에 서의 DNA 위치를 관찰하면 DNA 절단 정도를 확인할 수 있다. 단삼이 함유하고 있는 여러 물질 중에 salvianolic acid B는 주 요한 생리활성효능을 보이는 물질로서 항산화 효과가 보고된 바 있다[14]. 본 실험에서는 환원형 금속 이온인 $\mathrm{Fe}^{2+}$ 환경에서 salvianolic acid B의 항산화 효과를 확인하였다. $\mathrm{FeSO}_{4} 200 \mu \mathrm{M}$ 을 플라스미드에 처리했을 때 DNA가 절단되어 supercoiled 형 태가 사라지고 open circular 형태와 일부 linear 형태를 확인 할 수 있었다. $\mathrm{FeSO}_{4} 200 \mu \mathrm{M}$ 을 salvianolic acid B와 같이 처리 했을 때 처리 농도를 증가 할수록 linear 형태가 사라지고 supercoiled 형태가 증가함을 알 수 있다(Figure 2A). DNA를 플라스미드대신 Calf DNA로 바꾸었을 때 salvianolic acid B가 $\mathrm{Fe}^{2+}$ 에 의한 DNA 절단 억제를 좀 더 뚜렷이 알 수 있다(Figure 2B). 항산화 효과를 측정하는 방법으로 $\mathrm{Fe}^{2+}$ 킬레이팅능을 측정 하는데 본 실험에서 salvianolic acid B는 $\mathrm{Fe}^{2+}$ 과 ferrozine의 복합체 형성을 억제하지 못하였다(Figure 3). 이는 salvianolic acid $\mathrm{B}$ 가 $\mathrm{Fe}^{2+}$ 를 킬레이팅능이 뛰어나지 않음을 의미하며 Zhao 등[14]의 내용과 부합하는 결과이다.

\section{2. $\mathrm{Cu}^{2+}$ 이온 환경에서 salvianolic acid $\mathrm{B}$ 의 DNA 절단}

$\mathrm{CuSO}_{4}$ 를 단독으로 $200 \mu \mathrm{M}$ 처리했을 때, $\mathrm{FeSO}_{4}$ 처리와 달리 supercoiled 형태의 변화를 관찰 할수 없었다. $\mathrm{CuSO}_{4}$ 를 $200 \mu \mathrm{M}$ 로 고정하고 salvianolic acid B의 처리 농도를 증가할 때 $1 \mu \mathrm{M}$ 에서 open circular 형태를 관찰할 수 있었으며 $100 \mu \mathrm{M}$ 에서는 linear 형태가 보이고 $200 \mu \mathrm{M}$ 에서는 linear 형태위치에서부터 smearing 형태를 관찰 할 수 있었다(Figure 4A). Salvianolic

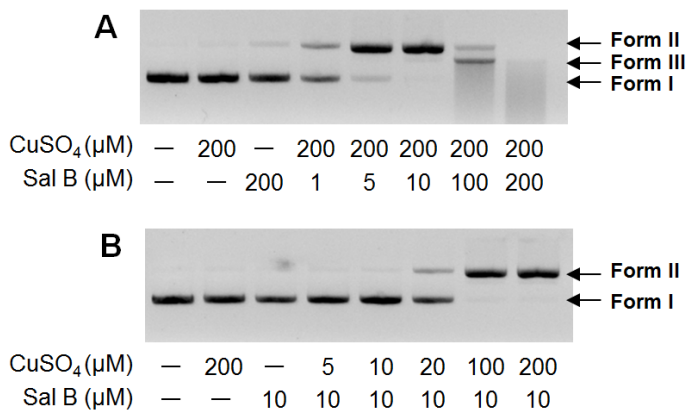

Figure 4. Induction of DNA breakage by salvianolic acid $B$ in the presence of $\mathrm{CuSO}_{4}$ ( $\mathrm{A}$ and $\mathrm{B}$ ). Electrophoresis was performed on $1 \%$ agarose gel. Form I, supercoiled form: Form II, open circular form: Form III, linear form. 
acid B 처리 농도에 비례하여 $\mathrm{DNA}$ 의 절단 정도가 심해짐을 알 수 있다. Salvianolic acid B를 $10 \mu \mathrm{M}$ 로 고정하고 $\mathrm{CuSO}_{4}$ 의 처 리 농도를 증가 할 경우 $20 \mu \mathrm{M}$ 에서 open circular 형태를 관찰 할 수 있었고 $100 \mu \mathrm{M}$ 에서는 완전히 open circular 형태만을 관 찰 가능하며 $200 \mu \mathrm{M}$ 에서는 $100 \mu \mathrm{M}$ 처리 때와는 달리 더 이상 의 DNA 분해는 관찰 되지 않았다(Figure $4 \mathrm{~B}$ ). $\mathrm{CuSO}_{4}$ 와 salvianolic acid B 단독 처리에서는 DNA 절단을 확인할 수 없 었으나 같이 처리 했을 때는 $\mathrm{DNA}$ 의 절단을 확인할 수 있었다. 이는 $\mathrm{Cu}^{2+}$ 와 salvianolic acid B의 반응으로 DNA 절단 하는 물 질을 생성했음을 의미한다. 환원된 형태의 금속은 용액 내 산소 와의 반응을 통해 ROS을 생산한다(Figure 1). 특히 hydroxyl radical은 가장 반응성이 큰 ROS로서 DNA 절단의 주요한 원인 이 된다[15]. $\mathrm{Cu}^{2+}$ 는 산화형태로서 salvianolic acid B에 의해 $\mathrm{Cu}^{2+}$ 가 환원되어 $\mathrm{Cu}^{+}$가 되고 이는 산소와의 반응을 통해 hydroxyl radical 생성되어 DNA를 절단 하였다고 가정해 볼 수 있다.

\section{3. $\mathrm{Cu}^{2+}$ 이온 환경에서 salvianolic acid $\mathrm{B}$ 에 의한 DNA 절단 기전}

이 실험에서 DNA 절단의 원인이 hydroxyl radical임을 확인 하기 위해 중간단계 생성물로 여겨지는 $\mathrm{H}_{2} \mathrm{O}_{2}$ 를 제거하는 catalase를 처리하여 DNA 절단을 관찰하였다. $\mathrm{CuSO}_{4}$ 와 salvianolic acid B의 처리농도를 각각 $100 \mu \mathrm{M}$ 과 $10 \mu \mathrm{M}$ 로 고 정하고 catalase처리 농도를 증가 할수록 open circular 형태가 사라짐을 관찰 할 수 있다(Figure 5A). 이는 catalase로 인해 $\mathrm{H}_{2} \mathrm{O}_{2}$ 가 제거되어 이 후 hydroxyl radical의 생성이 억제되었음 을 추론해 볼 수 있다.

$\mathrm{Cu}^{2+}$ 는 DNA의 특정 위치에 결합하여 ROS를 생성함으로서

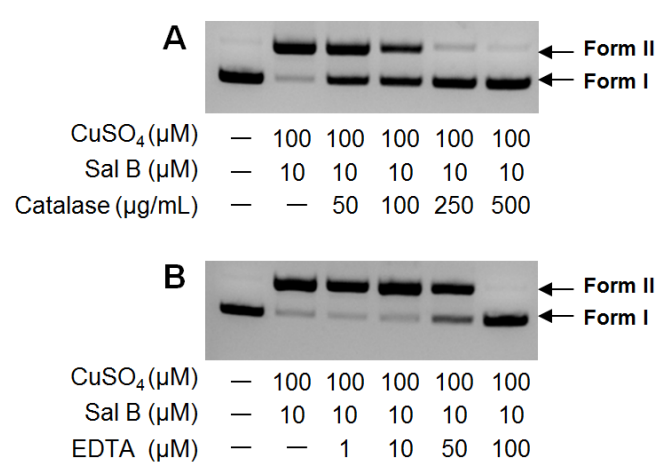

Figure 5. Preventive effect of catalase (A) and EDTA (B) on DNA breakage in the presence of salvianolic acid B and CuSO4. Electrophoresis was performed on $1 \%$ agarose gel. Form I, supercoiled form: Form II, open circular form: Form III, linear form.
$\mathrm{DNA}$ 의 절단이 용이해지며 $\mathrm{EDTA}$ 는 전이금속 킬레이터로서 $\mathrm{Cu}^{2+}$ 의 DNA 결합을 억제한다[16]. 본 실험에서 $\mathrm{CuSO}_{4}$ 와 salvianolic acid B의 처리농도를 각각 $100 \mu \mathrm{M}$ 과 $10 \mu \mathrm{M}$ 로 고 정하고 $\mathrm{EDTA}$ 를 처리하여 $\mathrm{DNA}$ 절단을 관찰하였다. EDTA 처리 농도를 증가시킬수록 open circular 형태가 줄어드는 것을 관 찰 할 수 있었다(Figure $5 \mathrm{~B}$ ). 이는 본 실험에서 $\mathrm{Cu}^{2+}$ 가 $\mathrm{DNA}$ 에 결합하고 salvianolic acid B와의 상호작용을 통해 $\mathrm{H}_{2} \mathrm{O}_{2}$ 를 생 성하고 최종적으로 hydroxyl radical을 생성하였다고 생각해 볼 수 있다.

\section{4. $\mathrm{Cu}^{+}$의 생성}

$\mathrm{Cu}^{2+}$ 는 산화형으로 hydroxyl radical을 생성하기 위해 환원 형으로 바뀌어야한다. Salvianolic acid B가 $\mathrm{Cu}^{2+}$ 를 $\mathrm{Cu}^{+}$로 변환 시키는지 알아보기 위해 $\mathrm{Cu}^{+}$에만 특이적으로 결합하는 킬레이 터인 neocuproine를 넣어 흡광도 측정하였다. $\mathrm{Cu}^{+}$와 neocuproine의 결합은 흡광도를 증가시킨다. Salvianolic acid B를 처리 농도를 증가할수록 농도 의존적으로 흡광도 증가하였다 (Figure 6). 이는 salvianolic acid B에 의해 $\mathrm{Cu}^{2+}$ 가 $\mathrm{Cu}^{+}$로 변환 됨을 의미한다. 위 결과를 종합하여 보면 $\mathrm{Cu}^{2+}$ 가 $\mathrm{DNA}$ 에 결합하 고 salvianolic acid B에 의해 $\mathrm{Cu}^{+}$로 환원되고 환원된 $\mathrm{Cu}^{+}$는 산 소와의 반응을 통해 $\mathrm{H}_{2} \mathrm{O}_{2}$ 를 거쳐 hydroxyl radical를 생성하며 이것이 DNA절단의 원인이 됨을 추론해 볼 수 있다.

\section{고 찰}

본 실험에서 환원형태의 $\mathrm{Fe}^{2+}$ 는 $\mathrm{DNA}$ 절단을 일으키지만 salvianolic acid B는 플라스미드와 Calf DNA에서 절단을 억제 하였고 산화형태의 $\mathrm{Cu}^{2+}$ 는 단독으로 $\mathrm{DNA}$ 절단을 일으키지 않

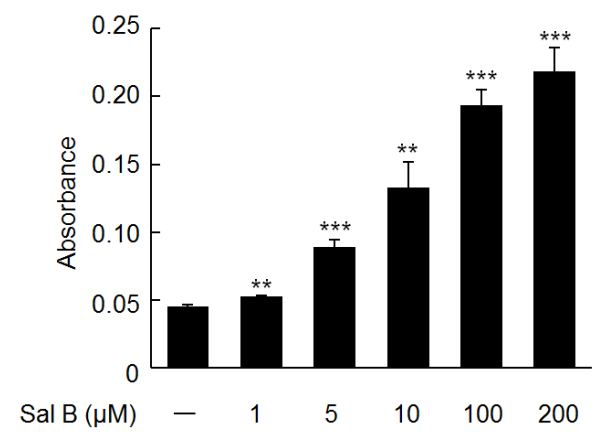

Figure 6. Transition of $\mathrm{Cu}^{2+}$ into $\mathrm{Cu}+$ by salvianolic acid $\mathrm{B}$. Neocuproine is $\mathrm{Cu}^{2+}$-specific chelator. Values represent mean \pm SD of three independent measurements. ${ }^{* * *} P<0.01,{ }^{* * *} P<0.001$; significantly different from the mixture of buffer and neocuproine without salvianolic acid B by Student's t-test. 
으나 salvianolic acid B를 첨가함으로서 $\mathrm{DNA}$ 의 절단을 확인하 였다. Catalase 및 EDTA 처리는 플라스미드의 절단을 억제하였 고 neocuproine를 처리했을 때 흡광도가 증가함을 확인하였 다. 이를 종합해 보면 $\mathrm{Cu}^{2+}$ 가 DNA와 결합하고 salvianolic acid $\mathrm{B}$ 와의 산화환원 반응을 통해 $\mathrm{Cu}^{+}$로 변환된 후 산소와의 일련의 반응을 통해 $\mathrm{H}_{2} \mathrm{O}_{2}$ 를 거쳐 hydroxyl radical을 생성한다고 볼 수 있다. 즉 산화형의 금속이 존재할 때 전자를 부여하는 능력이 산화형의 금속을 환원시키면 hydroxyl radical의 생성을 늘리 며 이것이 DNA을 절단한다고 생각되어진다. 이는 항산화능력 이 있다고 여겨지는 물질도 주위 금속 이온의 환경에 따라 pro-oxidant로서 기능을 수행함을 의미한다. 항산화 물질이 pro-oxidant로서 기능을 수행한다는 것이 유용하게 활용되어 질 수 있는데 특히 항암효과를 나타내는 기전으로 여겨진다. 정 상세포와 암세포의 차이점으로 구리이온의 증가한다는 보고 [17]는 구리이온이 증가된 암세포의 경우 phenolic compounds 등이 pro-oxidant로서 세포 사멸에 기여할 수 있음을 의미한 다. 최근 salvianolic acid B의 항암 효과를 보고한 논문이 발표 되었다. Wu 등[18]은 salvianolic acid B가 acute lymphoblastic leukemia 세포에 대해 독성이 있고 Guo 등[19]은 약물 저항성을 갖는 colorectal 암세포에서 salvianolic acid B가 $\mathrm{ROS}$ 를 증가시켜 apoptosis를 유발한다고 보고하였다. 즉 salvianolic acid B의 pro-oxidant 기능이 암세포를 사멸시키 는데 기여했다는 것이다. 본 연구에서는 salvianolic acid의 pro-oxidant 기능을 시험관내 실험으로 확인한 것일 뿐 암세포 및 동물실험에서 확인한 것은 아니다. 따라서 이런 salvianolic acid B의 DNA 절단 효과가 생체 내에서 나타날 것이라 할 수 없 다. 다만 이런 결과는 salvianolic acid B의 항암효과를 설명하 는 하나의 기전으로 ROS 생성을 고려해 볼 수 있다고 생각한다. 앞으로 다양한 암세포에 대한 salvianolic acid B의 독성효과와 그 기전을 설명하는데 있어 전이 금속상태와 ROS 생성 관계를 면밀히 살펴볼 필요가 있다고 생각한다.

\section{요 약}

단삼의 성분인 salvianolic acid B는 다양한 생리활성이 알려 져 있다. 특히 항산화 효과는 간세포, 신경세포를 포함한 다양한 세포유형에서 보호효과가 있다고 보고되었다. 하지만 ferulic acid와 같이 항산화제로 여겨지는 몇몇 페놀성 물질은 특정 전 이 금속이 있으면 산화작용을 하며 이것이 항암 효능을 설명하 기도 한다. 본 실험에서 salvianolic acid B가 $\mathrm{Cu}^{2+}$ 환경에서 산 화작용을 하는지 알아보았다. salvianolic acid B와 $\mathrm{Cu}^{2+}$ 를 동
시 처리하면 supercoilded 형태의 DNA가 open circular 혹은 linear 형태로 바뀌었으나 salvianolic acid B 혹은 $\mathrm{Cu}^{2+}$ 를 단독 처리 했을 때는 그렇지 않았다. $\mathrm{Cu}^{+}$에만 특정적인 킬레이터 neocuproine을 이용하여 salvianolic acid B가 $\mathrm{Cu}^{2+}$ 를 $\mathrm{Cu}^{+}$로 환원시킴을 알았으며 $\mathrm{H}_{2} \mathrm{O}_{2}$ 를 물과 산소로 분해하는 catalase 를 처리하면 DNA 분해가 일어나지 않았다. 활성산소종 중 하나 인 $\mathrm{H}_{2} \mathrm{O}_{2}$ 는 생체분자 특히 $\mathrm{DNA}$ 를 공격하여 정상기능을 수행하 지 못하게 한다. 정리하면 salvianolic acid B에 의한 $\mathrm{Cu}^{2+}$ 의 환 원은 $\mathrm{H}_{2} \mathrm{O}_{2}$ 를 생성하며 $\mathrm{H}_{2} \mathrm{O}_{2}$ 는 DNA 분해를 일으킨다. 이런 결 과는 salvianolic aicd B의 항암효과가 salvianolic acid의 $\mathrm{H}_{2} \mathrm{O}_{2}$ 생성 때문일 수 있다는 작은 단서를 줄수 있으며 이는 좀 더 실험 이 이뤄져야 한다.

Acknowledgements: This paper was supported by the Semyung University Research Grant of 2016.

Conflict of interest: None

\section{REFERENCES}

1. Halliwell B. Antioxidant defence mechanisms: from the beginning to the end (of the beginning). Free Radic Res. 1999;31: 261-272.

2. Deponte M. Glutathione catalysis and the reaction mechanisms of glutathione-dependent enzymes. Biochim Biophys Acta. 2013;1830:3217-3266.

3. Rajendran P, Nandakumar N, Rengarajan T, Palaniswami R, Gnanadhas EN, Lakshminarasaiah U, et al. Antioxidants and human diseases. Clin Chim Acta. 2014; 436: 332-347.

4. Murakami K, Haneda M, Qiao S, Naruse M, Yoshino M. Prooxidant action of rosmarinic acid: transition metal-dependent generation of reactive oxygen species. Toxicol In Vitro. 2007;21: 613-617.

5. Yoshino M, Haneda M, Naruse M, Htay HH, Iwata S, Tsubouchi $\mathrm{R}$, et al. Prooxidant action of gallic acid compoounds: copper-dependent strand breaks and the formation of 8-hydroxy-2'-deoxyguanosine in DNA. Toxicol In Vitro. 2002;16: 705-709.

6. Sarwar T, Zafaryab M, Husain MA, Ishqi HM, Rehman SU, Rizvi $\mathrm{MM}$, et al. Redox cycling of endogenous copper by ferulic acid leads to cellular DNA breakage and consequent cell death: A putative cancer chemotherapy mechanism. Toxicol Appl Pharmacol. 2015;289:251-261.

7. Quassinti L, Ortenzi F, Marcantoni E, Ricciutelli M, Lupidi G, Ortenzi C, Buonanno F, et al. DNA binding and oxidative DNA damage induced by climacostol-copper(II) complexes: implications for anticancer properties. Chem Biol Interact. 2013;206:109-116.

8. Bhat SH, Azmi AS, Hadi SM. Prooxidant DNA breakage induced by caffeic acid in human peripheral lymphocytes: involvement 
of endogenous copper and a putative mechanism for anticancer properties. Toxicol Appl Pharmacol. 2007;218:249-255.

9. Pang H, Wu L, Tang Y, Zhou G, Qu C, Duan JA. Chemical Analysis of the Herbal Medicine Salviae miltiorrhizae Radix et Rhizoma (Danshen). Molecules. 2016;21:51.

10. Tian LL, Wang XJ, Sun YN, Li CR, Xing YL, Zhao HB, et al. Salvianolic acid B, an antioxidant from Salvia miltiorrhiza, prevents 6-hydroxydopamine induced apoptosis in SH-SY5Y cells. Int J Biochem Cell Biol. 2008;40:409-422.

11. Liu CS, Chen NH, Zhang JT. Protection of PC12 cells from hydrogen peroxide-induced cytotoxicity by salvianolic acid B, a new compound isolated form Radix Salviae miltiorrhizae. Phytomedicine. 2007;14:492-497.

12. Zeng W, Shan W, Gao L, Gao D, Hu Y, Wang G, et al. Inhibition of HMGB1 release via salvianolic acid B-mediated SIRT1 up-regulation protects rats against non-alcoholic fatty liver disease. Sci Rep. 2015; 5:16013.

13. Wu HL, Li YH, Lin YH, Wang R, Li YB, Tie L, et al. Salvianolic acid $\mathrm{B}$ protects human endothelial cells from oxidative stress damage: a possible protective role of glucose-regulated protein 78 induction. Cardiovasc Res. 2009; 81:148-158.

14. Zhao GR, Zhang HM, Ye TX, Xiang ZJ, Yuan YJ, Guo ZX, et al. Characterization of the radical scavenging and antioxidant ac- tivities of danshensu and salvianolic acid B. Food Chem Toxicol. 2008;46:73-81.

15. Biaglow JE, Manevich Y, Uckun F, Held KD. Quantitation of hydroxyl radicals produced by radiation and copper-linked oxidation of ascorbate by 2-deoxy-D-ribose method. Free Radic Biol Med. 1997;22:1129-1138.

16. Lloyd DR, Phillips DH. Oxidative DNA damage mediated copper(II), iron(II) and nickel(II) fenton reactions: evidence for site-specific mechanisms in the formation of double-strand breaks, 8-hydroxydeoxyguanosine and putative intrastrand cross-links. Mutat Res. 1999;424:23-36.

17. Gupte A, Mumper RJ. Elevated copper and oxidative stress in cancer cells as a target for cancer treatment. Cancer Treat Rev. 2009;35:32-46.

18. Wu CF, Karioti A, Rohr D, Bilia AR, Efferth T. Production of rosmarinic acid and salvianolic acid B from callus culture of Salvia miltiorrhiza with cytotoxicity towards acute lymphoblastic leukemia cells. Food Chem. 2016;201:292-297.

19. Guo P, Wang S, Liang W, Wang W, Wang H, Zhao M, et al. Salvianolic acid B reverses multidrug resistance in HCT-8/VCR human colorectal cancer cells by increasing ROS levels. Mol Med Rep. 2017;15:724-730. 